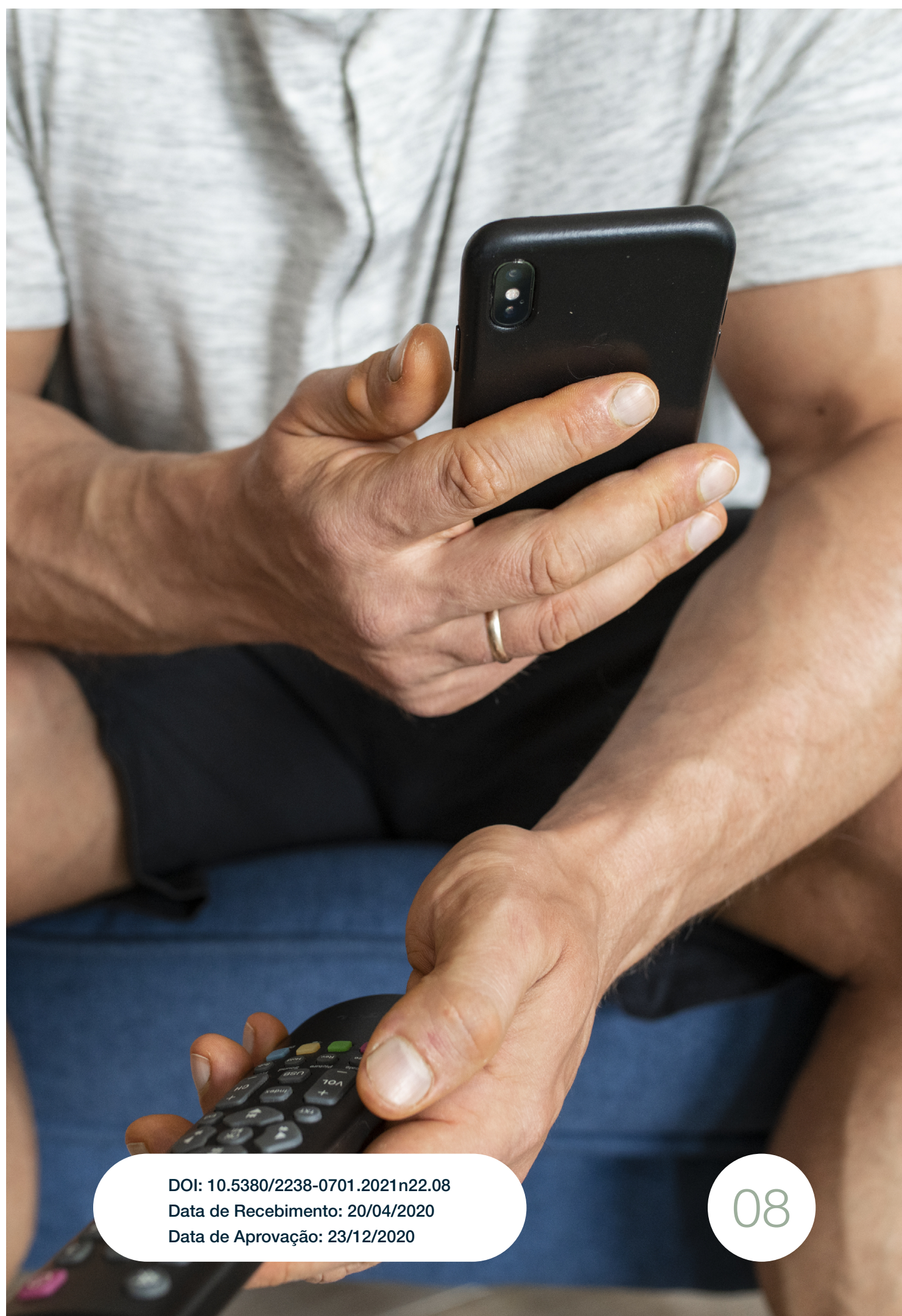


Meios massivos, audiências digitais: a campanha dos Cem Milhões de Uns e o modo de endereçamento da televisão em cenário de convergência 


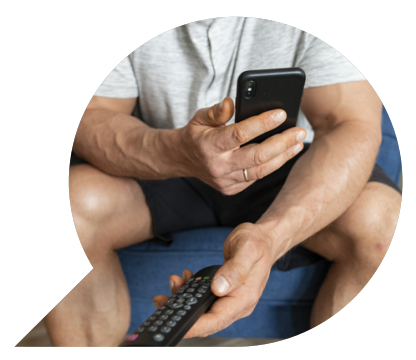

\title{
Meios massivos, audiências digitais: a campanha dos Cem Milhões de Uns e o modo de endereçamento da televisão em cenário de convergência
}

\author{
Massive media, digital audiences: the 100 Millions \\ of Ones and television's mode of address in a \\ convergence scenario
}

Medios masivos, audiencias digitales: la campaña de los 100 Millones de Unos y el modo de direccionamiento de la televisión en escenario de convergência

RODRIGO MARTINS ARAGÃO'

Resumo: Neste artigo, buscamos observar de que maneira as emissoras de televisão tentam se posicionar em relação às mudanças decorrentes do processo de convergência. Tomamos como caso de análise a campanha dos Cem Milhões de Uns, realizada pela Rede Globo, e transmitida entre os anos de 2017 e 2018. Observamos a campanha institucional como forma de a emissora construir e expressar sua imagem e propor uma forma própria de se relacionar com a sua audiência: seu modo de endereçamento. Seguindo a

1 Jornalista e professor adjunto do curso de Radialismo no Departamento de Comunicação da Universidade Federal da Paraíba. É Doutor em Comunicação pela Universidade Federal de Pernambuco (2019) e mestre em Comunicação e Cultura Contemporânea pela Universidade Federal da Bahia (2012). 
perspectiva teórico-metodológica dos modos de endereçamento, analisamos os vídeos da campanha. Identificamos que a emissora busca, por meio deles, evidenciar-se como empresa convergente, adaptada ao novo ecossistema midiático e atenta para atender às demandas de seu público digital.

Palavras-chave: Televisão; Convergência; Modo de endereçamento; Campanha; Rede Globo.

Abstract: In this paper, we seek to observe how television stations try to position themselves in relation to the changes due arising from the convergence process. We take as a case of analysis the Hundred millions of Ones campaign, developed by Rede Globo, and broadcasted between the years 2017 and 2018. We observe the institutional campaign as a means for the station to build and express its image and propose its own way of relating to its audience: its mode of address. Following the theoretical and methodological perspective of modes of address, we analyzed the campaign videos. We identified that the network seeks, through them, to show itself as a convergent company, adapted to the new media ecosystem and attentive to meet demands of its digital audience.

Keywords: Television; Convergence; Mode of address; Campaign; Rede Globo.

Resumén: En ese artículo nosotros averiguamos de que manera las emisoras de televisión intentan posicionarse frente a los cambios que transcurren del proceso de convergencia. Tomamos como objecto de análisis la campaña de los 100 Millones de Unos producida por Rede Globo y vehiculada entre los años de 2017 y 2018. Observamos la campaña institucional como una forma de la emisora construir y expresar su imagen y proponer su propria forma de relacionarse con su audiencia: su modo de direccionamiento. Siguiendo la perspectiva teórico-metodológica de los modos de direccionamiento, analizamos los videos de la campaña. Identificamos que la emisora intenta, través ellos, evidenciarse como una empresa convergente, adaptada al nuevo ecosistema mediático y atenta a atender las demandas de su audiencia digital.

Palabras-clave:Televisión; Convergencia; Modo dedireccionamiento; Campaña; Rede Globo. 


\section{Introdução}

A televisão foi por um longo tempo e se mantém, até hoje, como principal meio de comunicação utilizado pela população brasileira. O crescimento do acesso à internet e a serviços digitais de comunicação e conteúdo por demanda têm acarretado uma série de transformações no cenário de produção, circulação e consumo de produtos culturais e midiáticos. Os impactos desse processo são percebidos há alguns anos, e chegam a gerar questionamentos sobre o fim da televisão (CARLON, 2014; FECHINE, 2014).

Ainda que tal fim não tenha chegado, nem, aparentemente, esteja em horizonte próximo, parece consenso que transformações estruturais estão em processo. As emissoras de televisão têm se adaptado para assumir novas posições no cenário de convergência e, principalmente, estabelecer novas formas de se relacionar com uma audiência crescentemente adaptada à interação e às características personalizáveis e personalizadas da comunicação digital.

Neste trabalho, investigamos como esse processo de transformação tem sido traduzido pelas emissoras em uma atualização ou mudança em seus modos de endereçamento; conceito que compreende a "orientação de um programa para o seu receptor e de um modo de dizer específico; da relação de interdependência entre emissores e receptores na construção do sentido de um produto televisivo e do seu estilo" (GOMES, 2011, p. 36).

Para analisar não a relação de um programa com sua audiência, mas de uma emissora, tomamos como objeto de análise a campanha institucional 100 Milhões de Uns, realizada e veiculada pela Rede Globo nos anos de 2017 e 2018. A campanha, que toma como mote uma nova marca de audiência, também marca um novo lugar da emissora em relação ao seu público em meio a um novo ecossistema midiático. Além da análise dos vídeos da campanha, nos debruçamos sobre a observação do próprio processo de convergência que afeta meios de comunicação e audiências, e sobre o conceito de modo de endereçamento. 


\title{
Televisão e audiências em cenário de convergência
}

As mudanças atuais na televisão podem ser colocadas em perspectiva, como parte de uma trajetória de transformações. Mario Carlón (2014) apresenta um panorama e, a partir de leituras de Umberto Eco, Eliseo Verón e outros, indica uma trajetória de transformações dividida em três momentos chamados PaleoTV, NeoTV e Pós-TV.

\begin{abstract}
Se durante a PaleoTV, a instituição emissora se ocupou do "mundo exterior" (a televisão como "janela aberta para o mundo", como havia postulado Eco), e durante a NeoTV, a atenção foi dada à própria televisão e no vínculo com o sujeito espectador; na terceira fase, de crise da Instituição Emissora, o poder recai no espectador (CARLON, 2014, p. 15-16).
\end{abstract}

O pesquisador argentino destaca que essa crise da televisão se estabelece com base em mudanças que se relacionam aos dispositivos midiáticos e às práticas discursivas de produção e recepção de sentido ligados à televisão (CARLON, 2014, p. 17). Em relação às questões dos discursos midiáticos e sobre as mídias, Carlón (2009) assume uma perspectiva da semiótica, para observar como as mudanças de fases da televisão envolvem diferentes formas de se comunicar e se relacionar com sua audiência.

No primeiro momento, da PaleoTV, há uma concentração no conteúdo, na mensagem transmitida. Essa televisão tentou construir uma enunciação transparente e estabelecer "um contrato didático pedagógico, baseado em um modelo de educação cultural e popular, e se dirigia a um público massivo através de uma grade de programação clara" (CARLÓN, 2009, p. 167). A grade de programação era composta por conteúdos bem separados entre si por seus gêneros (informativo, infantil, ficcional) e que se destinavam, claramente, a públicos específicos e bem segmentados.

A PaleoTV dava destaque aos temas e assuntos, ou seja, aos conteúdos transmitidos, deixando que os seus textos fossem o destaque de sua programação e de sua relação com o público. Essa comunicação, que esconde ou não assume seu ato de produção, carrega um elemento de objetividade. 
A transição para a NeoTV está ancorada em uma mudança no contrato enunciativo que se estabelece entre a instituição emissora e seu público. A programação, o ato de programar e transmitir, passa a ter mais destaque do que o conteúdo que é transmitido. A enunciação se torna mais importante do que o enunciado quando "se funda a ideia de que os meios produzem sentido, e de que através dessa produção constroem os acontecimentos, em lugar de reproduzi-los ou representá-los" (CARLÓN, 2009, p. 168).

O contrato pedagógico é substituído por uma relação que tenta estabelecer uma simetria entre a emissora e o público, que passa a ser interpelado por uma programação menos rígida e em que os gêneros se misturam. A emissora troca "a interpelação de cada programa a um destinatário claramente delimitado para se dirigir genericamente 'à família', se impõe a coloquialidade dos talk shows” (CARLÓN, 2009, p. 169).

Novas tecnologias que dão ao espectador maior liberdade e poder de escolha sobre a programação e o crescimento de produtos televisivos em que os sujeitos comuns se tornam protagonistas, como os reality shows, participam do processo de transição para a Pós-TV (CARLÓN, 2009). Nesse momento, o processo de comunicação se concentra na figura do receptor, ou seja, no público, a quem se destina o conteúdo.

Esse cenário implica em uma crise do modelo de comunicação tradicional da televisão e uma quebra da sua atuação como um meio massivo. Carlón (2014) aponta três sintomas desse processo de transformação da televisão. Além de uma mudança estrutural no papel do espectador, uma crise do próprio meio de comunicação e o fim da programação como principal estrutura para o consumo de conteúdo televisivo, no cenário das múltiplas plataformas de compartilhamento que permitem acesso por demanda.

O último ponto, em especial, pode ser relativizado quando observamos que as estratégias de diálogo da televisão com outras mídias têm sido em busca de um fortalecimento da audiência televisiva e da própria programação. Essa percepção se fundamenta em considerações como as de Fechine (2014), ao observar que a incorporação ou atuação das emissoras em plataformas de redes sociais digitais, como é o caso das estratégias de TV Social², podem atuar para fortalecer o vínculo com o

2 Fechine (et al., 2017, p. 341-342) define TV social como um tipo de "conversação em rede e em ato em torno de conteúdos televisivos, realizada por meio de plataformas (redes sociais digitais) e tecnologias (aplicativos) interativas, atreladas a estratégias das indústrias televisiva [...] capazes de proporcionar o efeito de assistir junto a algo remotamente". 
acompanhamento em ato da programação a partir da lógica da copresença. Ao mesmo tempo, o crescimento das estratégias de oferta de conteúdo sob demanda pelas emissoras parece indicar que, senão um fim, também a programação enfrenta um processo de transformação.

Em relação a uma suposta crise da televisão como meio de comunicação, podemos destacar a crise de seu modelo de negócios baseado na publicidade, que tem também passado por transformações substanciais. Izabela Domingues (2015) descreve essa mudança de paradigma a partir da qual a publicidade deixa de atender a uma cultura de massas para adentrar e se integrar às sociedades de controle. Nesse cenário, a publicidade deixa de se comunicar com grupos indefinidos para aprender com os hábitos de consumo individual dos sujeitos e programar o consumo de forma personalizada para cada um deles. Como coloca a autora, essa nova publicidade se mostra

\begin{abstract}
programática, pluridirecional em função da comunicação em rede, colaborativa, ou seja, aberta à cocriação e ao diálogo com os consumidores e cidadãos, baseada no continuum do fluxo informacional, cuja linguagem vai se afastando dos paradigmas publicitários que constituíram a linguagem utilizada pelo setor ao longo do século XX (DOMINGUES, 2015, p. 263).
\end{abstract}

Essa mudança de paradigma que afeta a publicidade modifica o modelo de negócios da televisão e reitera a necessidade de mudanças para que as emissoras se mantenham relevantes e ativas no novo ecossistema midiático que se configura. A consolidação de uma Pós-TV, no entanto, não se resume a mudanças na forma de financiar, nas estratégias de programação e relação com outras plataformas de mídias. Tal qual a transição que se deu da PaleoTV para a Neo TV, o atual momento diz respeito, também, a uma mudança na forma como a televisão estabelece sua relação com a audiência e se comunica com ela. Se antes a emissora e a programação assumem papel central no processo, hoje, para se manter relevante, é necessário evidenciar que o principal elemento dessa comunicação é o público. O meio massivo, que se adapta à convergência, precisa, portanto, alterar a forma de se relacionar com essa audiência cada vez mais digital e estabelecer um modo de endereçamento condizente com o novo momento. 


\section{O conceito de modo de endereçamento}

O conceito de modo de endereçamento se populariza no campo dos estudos de cinema nos anos 1980. Devido à influência dos estudos culturais e das discussões sobre ideologia e identidade, o estudo dos modos de endereçamento traz como objetivo analisar os produtos a partir da forma como constroem um direcionamento à sua recepção. Esses estudos perguntam e tentam responder "quem esse filme pensa que você é?" (ELLSWORTH, 2001, p. 11).

A postulação da pergunta parte do pressuposto de que todo filme, desde a sua produção, precisa estabelecer uma projeção sobre sua audiência para que possa se direcionar a ela, fazê-la rir ou chorar.

O modo de endereçamento de um filme tem a ver, pois, com a necessidade de endereçar qualquer comunicação, texto ou ação "para" alguém. E, considerando-se os interesses comerciais dos produtores de filme, tem a ver com o desejo de controlar, tanto quanto possível, como e a partir de onde o espectador ou a espectadora lê o filme. Tem a ver com atrair o espectador ou a espectadora a uma posição particular de conhecimento para com o texto, uma posição de coerência, a partir da qual o filme funciona, adquire sentido, dá prazer, agrada dramática e esteticamente, vende a si próprio e vende os produtos relacionados ao filme (ELLSWORTH, 2001, p. 24).

O direcionamento à leitura proposto pelo modo de endereçamento, no entanto, não pode ser considerado absoluto. Muitas vezes, o espectador não é exatamente quem o filme pensa que ele é. Isso torna o processo de leitura da narrativa fílmica uma negociação que "depende da distância entre, de um lado, quem o filme pensa que somos e, de outro, quem nós pensamos que somos, isto é, depende do quanto o filme 'erra' seu alvo" (ELLSWORTH, 2001, p. 20).

O fato de que a ideia projetada do público não está sempre em consonância com o público real traz à tona um papel complementar do modo de endereçamento e de seu processo de posicionamento do sujeito. De acordo com Hartley (2004), o modo de endereçamento permite, por meio do discurso, que os produtos midiáticos convoquem suas audiências a ocuparem as posições que constroem para eles. Ao mesmo tempo que buscam dialogar com sujeitos específicos, os textos midiáticos interpelam os sujeitos para que assumam, em alguma medida, a posição prescrita pelo conteúdo que consomem. 
Está na base dessa discussão uma diferenciação essencial entre os conceitos de sujeito e indivíduo. Os indivíduos são os seres materializados, naturais, definidos pela cultura. Já os "sujeitos, não são pessoas materiais, mas existem apenas na interpretação dos textos e são construídos através do uso dos signos"3 (CHANDLER, 1994). A interpelação, então, é o processo de convocação dos indivíduos para que se reconheçam e assumam suas posições de sujeitos, a partir do reconhecimento da ideologia.

É por considerar que essa interpelação e convocação se dá através dos signos que Hartley (2004) compreende o modo de endereçamento como "um conceito referente aos processos que se dão dentro do texto para estabelecer uma relação entre o endereçador e endereçado" (p. 145). O autor traz como exemplo a transmissão de eventos esportivos de que participam uma equipe nacional. Durante a cobertura de eventos como esses, é comum a interpelação do sujeito "através da ideologia da nação [...]. O modo de endereçamento do comentarista assume ou demanda (convoca) um sujeito nacional” (p. 146) que reconhece a posição que deve ocupar - a posição de torcedor de sua seleção.

O autor destaca que esse elemento não é exclusivo dos produtos midiáticos, estando presente, inclusive, em interações face a face. Nesses casos, aponta Hartley, o modo de endereçamento pode ser identificado na maneira como adaptamos nossa forma de comunicar a depender de quem são os destinatários de nossas mensagens. Agimos e falamos de maneira mais leve e descontraída com um amigo ou familiar, enquanto assumimos um tom mais polido ao interagir com autoridades, por exemplo. Ou seja, o modo de endereçamento, está associado à forma como ajustamos nosso jeito de falar a partir da identificação de quem são os sujeitos a quem nos dirigimos e da relação que já temos ou buscamos estabelecer com eles.

Chandler (1994) amplia essa percepção de que os modos de endereçamento funcionam como "formas a partir das quais as relações entre um destinador e a quem ele se destina são construídas em um texto"4 (sem página) independentemente do tipo de texto. O autor evidencia esse ponto através de um resgate histórico de exemplos de como a pin-

3 No original: "Subjects are not actual people but exist only in relation to the interpretation of texts and are constructed through the use of signs".

4 "Modes of address can be defined as the ways in which relations between addresser and addressee are constructed in a text". 
tura e a fotografia, em suas técnicas, trabalham com o posicionamento dos sujeitos e destaca que, a partir do momento em que se utilizam da perspectiva em suas construções imagéticas, essas artes direcionam o olhar de seus espectadores e os posicionam diante dos textos, indicando como deve se dar sua leitura.

No audiovisual, seja no cinema, seja na televisão, Chandler (2004) identifica que, além dos elementos técnicos, como a perspectiva, há ainda a questão narrativa que passa a colaborar com a construção dessa posição dos sujeitos na sua leitura das obras. Três fatores influenciam diretamente a construção dos modos de endereçamento. O primeiro é o contexto textual, que se associa diretamente "às convenções do gênero e de uma estrutura sintagmática específica" 5 . Um segundo elemento é o contexto social, que diz respeito à presença ou não do produtor evidenciado no texto, e às questões sociais do leitor.

O último elemento diz respeito às condições próprias de cada meio de comunicação e que conduz e determina, em alguma medida, que características podem ser articuladas para estabelecer uma relação do produtor do texto com o sujeito que o lê no interior do próprio texto. Assim, a constituição de um modo de endereçamento específico se dá pela articulação dos contextos textual e social e das condicionantes tecnológicas de cada meio. Outras questões que ajudam a diferenciar os modos de endereçamento são o direcionamento ao público, a construção do ponto de vista narrativo e a formalidade ou distanciamento (CHANDLER, 1994).

O primeiro elemento diz respeito à forma como um produto se direciona ao público, acionando-o de maneira mais ou menos explícita. Chandler (1994) aponta que, mesmo raro, o direcionamento direto se dá quando um sujeito aparenta olhar diretamente para a câmera, gerando o efeito de encarar o espectador. A utilização desse recurso, o pesquisador aponta, restringe-se a alguns produtos, em que se propõe estabelecer um vínculo mais direto entre quem fala e quem recebe a mensagem, como programas jornalísticos. Enquanto os conteúdos de ficção, por exemplo, costumam evitar essa forma de evidenciação da construção do discurso de seu direcionamento ao público.

Essa característica se associa de maneira muito próxima à construção do ponto de vista narrativo. Esse elemento diz respeito à forma

5 No original: "the conventions of the genre and of a specific syntagmatic structure". 
como se estabelece a narração do produto, que pode ser realizada em primeira ou terceira pessoa, com narradores oniscientes ou subjetivos. Chandler (1994) indica que gêneros ficcionais, como filmes, costumam se valer de narrações em terceira pessoa, em que a história é contada por sujeitos externos a ela. Muitas vezes, inclusive, esses produtos tentam esconder toda a presença do narrador, dando a entender que os fatos ou eventos falam por si mesmos.

Outros gêneros, como os jornalísticos, costumam se utilizar de narradores em primeira pessoa, evidenciando os sujeitos que encadeiam as narrativas. Essa narração pode se dar de maneira individualizada, por meio de um único narrador, ou, em algumas vezes, de maneira polifônica, quando a narração é compartilhada por múltiplas vozes, como é o caso especificamente do telejornal, quando articula as vozes de apresentadores e repórteres.

A formalidade, ou distância social, diz respeito mais especificamente à forma de relação ou interação que se estabelece entre os sujeitos envolvidos no texto. Chandler (1994) aponta que o modo de endereçamento pode variar entre níveis mais ou menos formais, a depender da relação impessoal (ou pública), social, pessoal ou íntima.

Essas formas de relação entre os sujeitos, mais perceptíveis quando das interações face a face, podem também ser evidenciadas nos diversos textos. Mais facilmente identificada em elementos da linguagem verbal, a distância ou proximidade entre produtor e consumidor dos produtos midiáticos também pode ser estabelecida por meio de elementos técnico-expressivos, como enquadramentos de câmera, por exemplo.

Planos mais fechados e, portanto, mais próximos dos sujeitos em cena, podem indicar maior proximidade entre quem fala e o público a quem o produto se destina, e planos mais abertos, podem expressar uma maior distância. Esse distanciamento pode "refletir tentativas de encorajar envolvimento ou distanciamento crítico do observador"6 (CHANDLER, 1994).

A articulação desses elementos, como pontuamos anteriormente, dá-se de maneira específica em cada produto, levando em consideração, também, as regularidades do gênero e as características do meio de comunicação. Estudos no campo do telejornalismo têm consolidado os modos de endereçamento como chave para investigar como "um

6 No original: "reflects attempts to encourage feelings of emotional involvement or critical detachment in the viewer". 
programa específico tenta estabelecer uma forma particular de relação com sua audiência" (GOMES, 2011, p. 33).

A partir de elementos semióticos e da linguagem televisiva, assim como dos elementos verbais dos telejornais (GOMES, 2011) ou da forma como enquadramentos, movimentos de câmera e composição cenográfica dos noticiários (GUTMAN, 2012), os estudos sobre os modos de endereçamento dos programas telejornalísticos evidenciam as formas distintas a partir das quais os telejornais interpelam suas audiências. Daí ser possível identificar que diferentes produtos telejornalísticos de uma mesma emissora articulem diferentes modos de endereçar à sua audiência (GOMES, 2008; 2011).

O fato de poderem e serem mais amplamente estudados no âmbito de produtos específicos, no entanto, não implica que as emissoras não adotem, elas mesmas, modos de endereçamento próprios em relação a suas audiências. Isso porque as emissoras não transmitem suas produções como textos e produtos isolados, mas sim como parte de um encadeamento sequencializado e inserido em uma lógica própria, a da sua programação. Ou seja, é a partir da programação (que funciona como um texto englobante) que as emissoras consolidam as mensagens de seus programas (considerados textos englobados) em uma mensagem única e própria (FECHINE, 2008).

Observar o modo de endereçamento de uma emissora, considerando sua programação, torna-se um desafio mais complexo, uma vez que busca dialogar com públicos distintos entre si. Hartley (2004) destaca que, no caso das emissoras de televisão, o modo de endereçamento também permite estabelecer características de quem produz o texto para que sejam levadas em consideração quando de sua leitura. Ele explica que "emissoras de televisão utilizarão modos de endereçamento como forma de se diferenciarem e tornar únicas as formas de programação que oferecem" (2004, p. 146).

Nesse caso, tanto quanto posicionar sua audiência, as emissoras buscam se mostrar a ela, utilizando, por exemplo suas campanhas de divulgação e de programação, haja vista que é nesses textos que a emissora se apresenta como unidade, e não como um mero conjunto de outros textos, seus programas e conteúdos.

Assim, analisamos a seguir a campanha institucional da Rede Globo dos 100 Milhões de Uns como forma de estabelecer uma mensagem sobre si, posicionar-se diante de sua audiência e estabelecer com 
ela uma relação específica que a distinga das outras emissoras de televisão. Ou seja, um modo de endereçamento.

\section{A campanha dos 100 Milhões de Uns e a nova percepção da audiência}

A campanha dos 100 Milhões de Uns foi lançada pela Rede Globo em 2017 e posteriormente reforçada em 2019 com novos vídeos. A emissora comemora o recorde de audiência de cem milhões de pessoas diariamente, o maior índice desde o ano de 2011. Mais do que celebrar um índice, no entanto, a campanha busca passar uma mensagem. Ao comunicar o crescimento de seu alcance em meio a um cenário de maior acesso aos meios de comunicação e serviços digitais, a emissora busca evidenciar suas características e sua posição nesse novo ecossistema midiático e atualizar as formas como o seu público, cada vez mais digital, pode se relacionar com ela.

Lançada no dia 22 de outubro de 2017, durante o Fantástico, a campanha 100 Milhões de Uns celebra a marca de audiência recorde da emissora no território nacional. Durante o anúncio, a emissora reforça sua posição de liderança na comunicação nacional, indicando que "leva o melhor do jornalismo, do entretenimento, do esporte a todos os cantos do país" (G1, 2017) e que a campanha renova seu compromisso com o espectador.

Os primeiros vídeos da campanha foram narrados por nomes conhecidos da emissora, como Danton Mello e Eliane Giardini, e trouxeram um mesmo texto, que faz as vezes de um manifesto, em que a emissora se direciona ao espectador.

Todo o Brasil assiste a Globo. São mais de Cem Milhões de pessoas todos os dias, mas a gente sabe que não fala com esse tal de cem miIhões. A gente fala com cem milhões de uns. Uns diferentes de outros uns. Uns que se emocionam, uns que se informam. Uns que gostam da gente, uns que dizem que não. E a gente se movimenta para conquistar cada um. Porque a gente sabe que um desses cem milhões é você (REDE GLOBO, 2017). 
Cobrindo o texto, seguem sucessões de imagens em que podem ser vistos, de forma alternada, elementos diversos, primeiro em conjunto e, posteriormente, isolados, a exemplo da imagem de uma floresta seguida de uma planta brotando; ou de um quadro repleto de chaves, substituído na tela por uma única chave, ou de uma onda no oceano.

Os vídeos que deram continuidade à campanha mantiveram o padrão de sequência de imagens, mas trouxeram versões do texto cantado em ritmos como forró, samba e rock. A emissora reforça sua competência em se comunicar com todos, atendendo às necessidades, interesses ou gostos de cada um especificamente. Com a campanha, a emissora assume uma postura de se direcionar de maneira direta ao seu espectador e se aproximar dele. Mesmo falando com todos, reconhece e se movimenta para chegar a cada um.

A imagem da campanha (Figura 1), além de trazer o texto e uma representação imagética que repete a sucessão de imagens presente no vídeo, apresentando o cardume e o peixe isolado, resume, em alguma medida, o tom inicial da nova proposta da emissora: "Para a Globo você não é mais um, é o um".

Figura 1 - Imagem da campanha dos 100 Milhões de Uns.

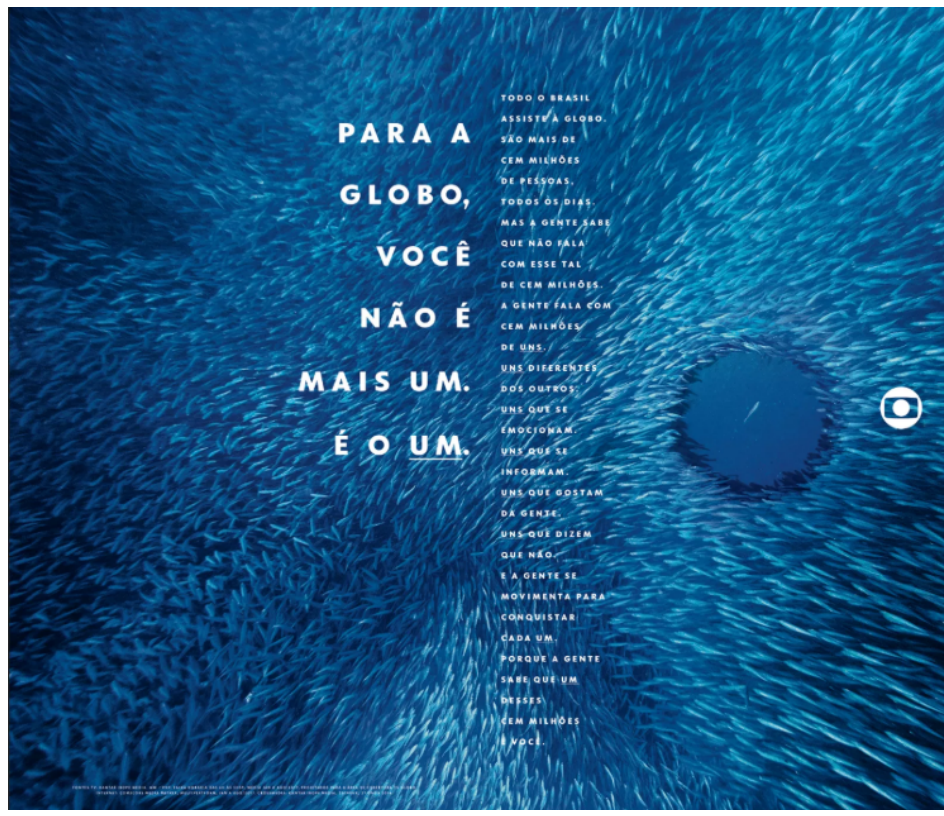

Fonte: Rede Globo. 
Já de início, podemos perceber, nesse enunciado, uma relação direta com uma das principais marcas da chamada Pós-TV, em que, como estabelecido anteriormente, é marcada pela nova configuração do espectador, que - ao menos no discurso televisivo - ganha força e passa a ter maior relevância no processo comunicativo. A emissora, mesmo comemorando um alcance de milhões de pessoas, tenta demonstrar que se preocupa com cada um, e se modifica para alcançar cada um individualmente.

Uma questão reforça a leitura de que a emissora utiliza a campanha para passar um recado sobre si mesma e, assim, fortalecer e reforçar sua forma de se relacionar com o público e se posicionar no novo ecossistema midiático. Ainda que não registre a informação nos vídeos iniciais da campanha, a audiência que a emissora celebra não representa apenas os índices de espectadores televisivos, mas o público conjunto de todas as suas plataformas, incluindo as digitais, como Globoplay e G1 (REDE GLOBO, 2017). Mesmo que sutilmente, fica evidente que a Globo a que todos assistem não é mais apenas uma emissora de televisão, mas uma empresa de mídia, inserida em um cenário de convergência e de consumo multiplataformas.

Isso fica evidenciado nos vídeos que deram continuidade à campanha ao longo do ano de 2018, em que a Globo apresenta alguns indivíduos que integram os 100 milhões de uns. Narrados por atores e atrizes, como Patrícia Pillar e Vladimir Brichta, os vídeos apresentam brevemente um indivíduo, sua rotina, seus interesses e sua relação com a Rede Globo.

Sempre chamado os sujeitos pelo primeiro nome, uma forma de demonstrar a singularidade do indivíduo e em alguma medida uma proximidade da emissora para com ele, esse sujeito é identificado em seus interesses e afazeres, suas relações ou gostos. As imagens reforçam esse cotidiano descrito, complementando e reiterando, em especial, a presença da emissora na rotina dos sujeitos, mostrando-a ser acessada em situações diversas e a partir de algumas de suas plataformas distintas.

Os vídeos servem como formas de exemplificar discursivamente os sujeitos, provocando identificação com o público em geral, e, em especial, com os uns. Os vídeos apresentam os personagens que materializam, em alguma medida os uns (ou o um) listados no texto da campanha principal. Em um vídeo, a personagem representa o público 
tradicional da emissora, que "durante todo o dia [...] tem um encontro com tudo o que passa na Globo. Porque enquanto a Rita não desliga, ela não desliga a Globo também" (REDE GLOBO, 2018a).

Em outra peça, são apresentadas duas empreendedoras, que se emocionam e se informam com os conteúdos, mas já não seguem a programação televisiva à risca. Consomem as produções da emissora depois de um dia de trabalho, cada uma a seu modo - "A Carol vê as séries das onze. A Ju vê o jornal da Globo” (REDE GLOBO, 2018b). Nas imagens (Figura 2), a emissora mostra que a forma de acesso ao conteúdo se dá em plataformas distintas que não a tela da televisão, mas de plataformas móveis, por meio do Globoplay. O que reforça a imagem da emissora como participante ativa de um cenário complexo de convergência tecnológica e midiática e próxima das suas audiências em suas novas dinâmicas.

Figura 2 - Juliana e Carolina assistem ao Bom Dia Brasil por Tablet.

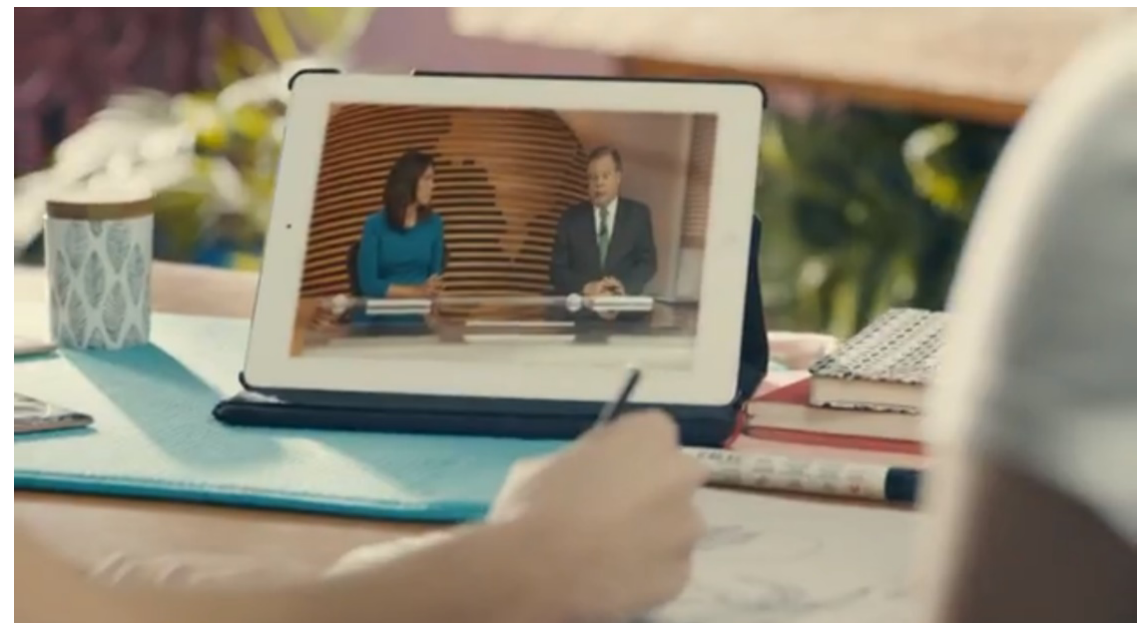

Fonte: Rede Globo (2018).

Outro vídeo da campanha que reforça essa comunicação em que se propõe uma nova relação com o público é aquele em que a emissora reconhece os sujeitos que, segundo ela, dizem não gostar da Globo. A peça apresenta um homem jovem que "quase nunca vê a Globo. A não ser quando tem jogo do time dele. Quando tem notícia do time dele. Quando tem notícias dos adversários do time dele. E a não ser quando tá vendo o zero um" (REDE GLOBO, 2018c). 
Nas imagens, vê-se um indivíduo conectado, que recebe uma notificação para o início de uma partida de futebol e que, em seguida, destina-se a um bar para assisti-lo na companhia de amigos. O vídeo evidencia uma relação quase que utilitária do público com a emissora, em que se reforça uma postura de atender às demandas dos indivíduos que se tornam o centro do processo comunicacional.

O papel discursivo dessas campanhas, ao reforçar a estratégia de identificação e proximidade com o público, fica ainda mais evidente quando, ao final de cada vídeo, a assinatura afirma que conhece esses sujeitos e todos aqueles como eles. A emissora informa, tentando diminuir seu distanciamento em relação à audiência, que "Todos eles juntos fazem parte dos 100 milhões de uns que passam todos os dias pela Globo. Como você." (REDE GLOBO, 2017).

Esses vídeos reforçam que a emissora está celebrando uma nova forma de se relacionar com seu público. Um modo de endereçamento baseado na proximidade e na atenção e compreensão das especificidades dos indivíduos que compõem sua audiência e que atualiza a imagem da emissora que se encontra, agora, em movimento e atualização diante do cenário da convergência e inserida no novo ecossistema comunicacional.

Outra mudança importante que reforça a nova postura da emissora no atual cenário é que a campanha também se torna o nome da nova plataforma digital de inteligência de mercado da empresa que carrega o título da campanha: Milhões de Uns. No entanto, em lugar de se voltar para a audiência tradicional, esta é voltada para outro público, que também mantém relação com a emissora: os anunciantes. Por meio dela, a Globo comunica a anunciantes, agências e outros atores do mercado de mídia que pretende "compartilhar tudo que a gente sabe sobre comportamentos, mercados, particularidades regionais, tendências, movimentos sociais etc." (REDE GLOBO, 2017a).

A plataforma marca "uma mudança na forma de embalar e compartilhar as milhares de informações que temos sobre quem consome nossos conteúdos todos os dias, nas nossas diversas plataformas, em todos os cantos do Brasil" (REDE GLOBO, 2017a).

A campanha, então, busca reposicionar a Globo em relação à sua audiência e a seus anunciantes. É interessante percebermos, principalmente ao tomar como base o fato de que a campanha também dá nome a uma estratégia de diálogo com anunciantes, o quanto essa 
proposta de traçar perfis dos sujeitos se assemelha à definição de uma Persona para o marketing. Essas são "representações ficcionais, específicas e concretas de usuários-chave" que quando materializadas em ilustrações, dados e esquemas, "dão rosto ao usuário - imagem memorável, engajadora e acionável que serve como alvo (PRUITT, ADLIN, 2006, p. 11 apud SILVA, MARTINS, 2016, p. 195).

Essa forma de representação tem se tornado cada vez mais necessária no atual cenário de convergência e maior autonomia e poder de decisão dos usuários sobre seus consumos midiáticos e de compreensão das subjetividades de forma complexa e permeada por experiências ao mesmo tempo individuais e compartilhadas com grupos. São base para comunicação de empresas e marcas que dialogam com o cenário de imbricação de meios de comunicação de massa e de redes de função pós-massiva e atuam a partir de estratégias mistas de marketing digital e publicidade de controle (DOMINGUES, 2015).

Os vídeos articulam-se de modo a consolidar nosso entendimento de que a campanha dos 100 Milhões de Uns se destina, a um só tempo, ao público da Rede Globo e a seus grupos de anunciantes. Da mesma forma, reforça nossa leitura de que, em seu texto, a campanha explicita uma trajetória de mudança da emissora, sua inserção no cenário de convergência, compreensão das transformações da audiência e dos processos de consumo midiático e de proposição de uma nova relação entre produção e recepção: um novo modo de endereçamento.

\section{Considerações finais}

Percebemos, com esta análise, que a emissora confirma sua inserção no processo e no cenário de convergência, assumindo cada vez mais a importância das novas mídias digitais de interação, sem abrir mão de seu protagonismo no ecossistema convergente. O que é visível quando a audiência de outras plataformas é incorporada na contagem dos seus 100 milhões, sem explicitar que é dessa forma que chega a esses números.

Também busca se colocar como elemento mediador desse processo de navegação e circulação de informações em rede, quando apresenta, visual e textualmente, o uso dessas plataformas para consumo 
de conteúdo televisivo ou que seja minimamente atrelado a ele. Tal discurso tensiona a emissora a estabelecer e experimentar um conjunto de novas ações que educam o público para que realize uma articulação de mídias em torno da televisão.

Para consolidar essa nova postura, a emissora atualiza sua forma de se relacionar com o público, seu modo de endereçamento, consolidando uma postura mais próxima da audiência. Porém não mais uma audiência massiva e homogênea atingida de maneira indistinta pela programação, mas uma audiência digital, que utiliza dos conteúdos de maneiras distintas e por quem a emissora precisa se movimentar e modificar para alcançar.

\section{REFERÊNCIAS}

CARLÓN, Mario. Repensando os debates anglo-saxões e latino americanos sobre o "fim da televisão". In: CARLÓN, Mario; FECHINE, Yvana (orgs.). 0 fim de televisão. Rio de Janeiro: Confraria do Vento, 2014

- ¿Autopsia a la Televisión? Dispositivo y lenguaje en el fin de una era. In: CARLÓN, Mario; SCOLARI, Carlos A. (eds.). El fin de los medios massivos: El comienzo de un debate. Buenos Aires: La Crujía, 2009.

CHANDLER, Daniel. Semiotics for Beginners. 1994. Disponível em: http://www.aber.ac.uk/media/Documents/S4B/semiotic.html. Acesso em: 3 de janeiro de 2019.

DOMINGUES, Izabela. Da publicidade disciplinar à publicidade de controle: comunicação, vigilância e poder. Recife: Tese (Doutorado) - Universidade Federal de Pernambuco, CAC. Comunicação, 2015.

ELLSWORTH, Elizabeth. Modo de endereçamento: uma coisa de cinema; uma coisa de educação também. In: SILVA, Tomaz Tadeu da. Nunca fomos humanos - Nos rastros do sujeito. Belo Horizonte: Autêntica, 2001.

FECHINE, Yvana. Televisão e Presença: uma abordagem semiótica da transmissão direta. São Paulo: Estação das Letras e Cores, 2008

Elogio à programação: repensando a televisão que não desapareceu. In: CARLÓN, Mario; FECHINE, Yvana. O fim de televisão. Rio de Janeiro: Confraria do Vento, 2014

GOMES, Itania; MEDEIROS, Mariana. O pacto sobre o papel do jornalismo nos quatro telejornais diários da Rede Globo. In: Animus, v. 13, 2008-1.

GOMES, Itania (org.). Gênero televisivo e modo de endereçamento no telejornalismo. Salvador: EDUFBA, 2011. 
GUTMANN, Juliana. O que dizem os enquadramentos de câmera no telejornal? Um olhar sobre formas audiovisuais contemporâneas do jornalismo. In: Brazilian Journalism Research, v. 8, n. 2, 2012

G1. 2017. Globo fala com mais de cem milhões de pessoas a cada dia. Disponível em: http:// g1.globo.com/fantastico/noticia/2017/10/globo-fala-com-mais-de-cem-milhoes-de-pessoas-cada-dia.html. Acesso em: 15 de abril de 2020.

HARTLEY, John. Communication, Cultural and media studies: The key concepts. London: Routledge, 2004.

REDE GLOBO. 2017. Globo celebra alcance de mais de 100 milhões de pessoas por dia. 23/10/2017. Disponível em: https://redeglobo.globo.com/novidades/noticia/globo-celebra-alcance-de-mais-de-100-milhoes-de-pessoas-por-dia.ghtml. Acesso em: 13 de abril de 2020.

2017a. Milhões de uns. 2017a. Disponível em: http://redeglobo.globo.com/milhoesdeuns. Acesso em: 13 de abril de 2020.

. 2018a. Rita é uma das 100 milhões de uns. 13/08/2018. Disponível em: http://www. globo.com/busca/?q=rita+100+milh\%C3\%B5es\&page=1. Acesso em: 13 de abril de 2020.

2018b. Juliana e Carolina fazem parte dos 100 milhões de uns. 13/08/2018. Disponível em: http://redeglobo.globo.com/videos/t/rede-globo/v/juliana-e-carolina-fazem-parte-dos-100-miIhoes-de-uns/6941596/. Acesso em: 13 de abril de 2020.

. 2018c. Marcos é um dos 100 milhões de uns. 13/08/2018. Disponível em: http:// redeglobo.globo.com/videos/t/tudo-da-globo/v/marcos-e-um-dos-100-milhoes-de-uns/6941468/. Acesso em: 13 de abril de 2020.

SILVA, Tarcízio; MARTINS, Yuri. Criando personas e ilustrações. In: SILVA, Tarcízio; STABILE, Max (orgs.). Monitoramento e Pesquisa em Mídias Sociais: Metodologias, aplicações e inovações. São Paulo: Uva Limão, 2016. 


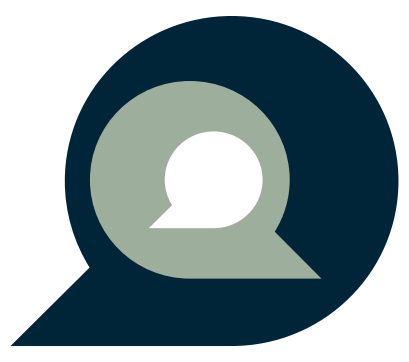

